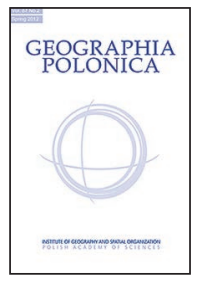

\title{
POLISH SHOPPING MALLS ATTRACTIVENESS IN THE OPINION OF YOUNG CONSUMERS: STRUCTURAL MODELLING (SEM)
}

\author{
Anna Irena Szymańska ${ }^{1}$ (D) Monika Płaziak² \\ ${ }^{1}$ Management Institute, Department of Trade and Market Institutions \\ Cracow University of Economics \\ ul. Rakowicka 27, 31-510 Kraków, Poland \\ e-mail: szymansa@uek.krakow.pl (corresponding author) \\ ${ }^{2}$ Institute of Geography, Department of Geography of Urban and Rural Areas \\ Pedagogical University of Krakow \\ ul. Podchorążych 2, 30-084 Kraków, Poland \\ e-mail: monika.plaziak@up.krakow.pl
}

\begin{abstract}
The main goal of this paper is the discussion of key factors that determine the underlying motivation of certain kinds of young consumer behavior in terms of selection of shopping malls as places of shopping for goods and services. The identification was based on an available literature and on a verification of the power of influence of selected determinants on the underlying motivation of consumer behavior. A theoretical model is proposed, which has been subjected to a verification process using structural modeling (SEM). The authors observed significant relationships between principal factors such as personal factors, mall environment, situational factors, and mall visiting among young consumers. Furthermore, in the opinions expressed by young shoppers, the mall environment and situational factors were significantly higher rated than personal factors. In addition, the authors found that the young shoppers' personal factors section needs improvement.
\end{abstract}

\section{Key words}

shopping mall • SEM modeling • consumer behavior

\section{Introduction}

Shopping malls are an important feature of urban space and at the same time serious competition for remaining forms of retail establishments. They offer a wide range of products and services, promotional campaigns, taste tests, ample mall parking facilities and gas stations, as well as a variety of stores located within the shopping complex. Moreover, as an effect of the multidirectional influence of shopping malls (spatial, economic, social), malls have become a subject of interest in many scientific circles. Malls have 
become a subject of interest primarily to the technological sciences, social sciences, economics, and socioeconomic geography.

The principal goal of this paper is to identify key determinants influencing decisions of consumers in terms of selection of shopping malls as places of purchasing and use of services. The identification is based on an analysis of research literature on the subject and on verification of the power of influence of selected determinants on the underlying motivation of specific kinds of consumer behavior.

A theoretical model is proposed in the paper. Initially, the model consisted of four exogenous variables, one endogenous latent variable, and thirty five observable variables describing them. The model was subsequently verified by testing using structural modeling (SEM).

Data used in the modeling procedure were obtained earlier in the process of empirical research performed with the participation of a group of 550 interviewees. All calculations were performed using the SEPATH module of STATISTICA13 software.

\section{Shopping malls as research subjects: Literature review}

The first scientific study of shopping malls was conducted in the 1940s (Lillibridge, 1948). The study was primarily focused on architectural and urbanistic aspects, presenting projects and descriptions of a new type of building, which became known as the mall (Baker \& Funaro, 1951; Gruen \& Smith, 1952). Questions regarding location were considered (Feiss, 1940; Gruen, 1943). Other matters discussed included spatial distribution and type of lessees (Dowling, 1943, 1944) as well as the potential impact of suburban shopping malls on the spatial development of cities and transportation solutions (Kelly, 1956).

Research papers soon appeared treating the shopping mall as a new trend in retail (Merts, 1949), describing strategies of retailers and sales staff of these new shopping districts regarding how to compete with shopping centers located on the outskirts of cities (Fisher, 1950). The purpose of this type of shopping facility was the development of suburban areas and the amorphous structure of urban agglomeration, as well as the strengthening of social life of the population living in peripheral parts of cities serving as a meeting place during the process of consumption (Boeckl, 1995; Hardwick, 2004).

Four main research views emerged in the second half of the 20th century that focused on shopping malls: technical view, locationbased view, economic and organizational view, and a behavioral view (Eppli \& Benjamin, 1994; Solal, 1998; Tubridy, 2006). The technical view encompasses the project and engineering aspects, starting with the preparation of an architectural design and urbanistic composition through the construction process and up to urbanistic detail (Coleman, 2006; Teller, 2008; Aktas, 2012; Kusumowidagdo et al., 2015; Haoying et al., 2019).

Issues that are also discussed as part of the technical approach relate to the development of the spaces around shopping malls, a vital element of which is the local transportation infrastructure, land development and landscaping around the shopping mall, and parking area. Additionally, a shopping mall's surroundings should include a set of elements such as a park, boardwalk, or amphitheater suitable for consumer needs and simultaneously preserving spatial order in the surrounding neighborhood (Dawson \& Lord, 1985; El-Adly \& Eid, 2016; Płaziak \& Szymańska, 2018).

Shopping malls are criticized in many research works because of their excessive physical size and destruction of the historic structure of cities (Jałowiecki, 2005; Setkowicz, 2008), which is a consequence of the commercialization of architecture and subordination of urban solutions to marketing strategies (Chase, 1991; Pedreschi, 2000). On the other hand, however, shopping malls in Western countries are the third place (after home and workplace) in terms of the length of time spent by people in a particular environment (Naisbitt, 1997). 
With the inception of the location research approach at the end of the 1940s, research was begun that focused on the identification of variables describing locations of shopping malls. The research was to systematize established location factors and to find more location factors (Yue-min, 1984; Płaziak \& Szymańska, 2014), and to create spatial distribution models showing their areas of influence. To accomplish this, researchers used existing theories and models including location theories by $\mathrm{H}$. Hotelling (1929), W. Christaller (1933), A. Lösh (1940), and W. Alonso (1964), network theories, spatial interaction model theories, and eclectic theory of international production by J.M. Dunning (Sternquist, 1997).

Two types of locations have been identified in studies on the development of shopping malls (Cohen, 2002; Söllner, 2009) so far:

- in peripheral zones, outside of built-up areas, close to highway intersections or other major thoroughfare intersections (Górka \& Trzepacz, 2006; Kuc-Słuszniak, 2008a), where numerous service facilities also operate including warehousing and shipping centers, business centers, scientific centers, recreational facilities, and production plants, which create economic activity zones part of new information economy cities, exemplifying the so-called edge city (Garreau, 1991; Lowe, 2000).

- inside the structure of leading urban centers (Frieden \& Sagalyn, 1991; Kuc-Słuszniak, 2008b), which contributes to a revitalization of central parts of cities and entails the revitalization of post-industrial areas and various degraded sites (Tölle, 2007).

An important issue in research is also the analysis of changes that shopping malls cause to the structure of the city (Mumford, 1961; Longstreth, 1997). Shopping malls, by creating new 'hearts' of cities, change the traditional structure of the urban center, causing decentralization of the greater city area, taking over public spaces (Staeheli \& Mitchell, 2006; Rochmińska, 2016).

The economics and organization perspective includes research work on the conditions and relationships occurring in the sphere of production, distribution, consumption of goods, and marketing as well as development and management of large-area commercial facilities offering multiple services. Questions that are examined are related to the processes of concentration and evolution of trade, effect of shopping malls on the development of strategy of the competition and means of competing in the market of large floor area shopping facilities as well as planning, implementation, and control of marketing strategies (Sit et al., 2003).

Relationships between the consumer and the shopping mall are also examined (Dennis, 2005; Dębek, 2015; Szymańska \& Płaziak, 2017; Szymańska, 2018). Such research contributes to the strengthening of the shopping mall by improving its key weak sides, which translates itself into, for example, interior decoration improvements, or some forms of the introduction of cultural and entertainment institutions, which effectively helps lead to maintaining the existing customer base and attracting new customers (Arnold \& Reynolds, 2003; Szymańska \& Płaziak, 2018). An important issue is sales on the internet, conducted through e-stores and auction platforms, which may now be called virtual shopping malls (Massagli, 2000; Hendershott, Hendershott \& Hendershott, 2001).

The behavioral approach focuses on the functioning of consumers in the modern era of consumerism (Aldridge, 2006; Feng \& XiaoTing, 2015). What is highly essential is the development of consumption as an important aspect of the life of man, for whom shopping has become a key sign of social activity (Clarke, 2003; Chebat et al., 2014). A shopping mall is portrayed as a permanent element of social life having a cultural or even religious significance (Kramer, 1996), an element that has an influence and presence in human life in the form of a place to spend spare time, also a tourist facility or some source of inspiration to artists (Davis, 1991). This research approach unifies all research relating to the shopping mall issue. This view emphasizes the fact that the shopping mall 
was designed by people with the idea that it is for people, and that it will serve them as a meeting place that will facilitate the initiating and maintaining of social relationships while shopping (Hardwick, 2004; Baker \& Wakefield, 2012; Szymańska \& Płaziak, 2021).

\section{Research hypothesis and theoretical model}

The identification of key factors determining the choice of the shopping mall as a place of purchasing and use of services was made based on an analysis of the literature on the subject. Subsequently, these factors were arranged into four key groups, namely: personal factors (PF), emotional factors (EF), mall environment (ME), and situational factors (SF). The classification was made based on research work performed by Liaw (2007), Hu and Jaspers (2007), Meneely et al. (2009), Petermans and Van Cleempoel (2010), Walker and Mesnard (2012), Rousseau and Venter (2014). These authors showed that the aforementioned groups of factors (PF, EF, ME, SF) significantly influence the shopping mall visiting pattern (MV). The specified groups of factors were selected as characteristic and independent categories, within which the research hypotheses were stated.

An argument for the rightness of undertaking empirical research was the need to verify whether the factors specified in the literature also affect the behavior of consumers in Poland. Systemic and economic changes that took place in Poland after 1989 contributed to the dynamic development of trade and services. The first shopping centers were not built here until the early 1990s, and in the following years there was a systematic increase in the number of shopping centers opened.

Personal factors such as perceived needs, lifestyles, and values may influence consumer expectations, key consumer choices, and consumer behavior at shopping malls. Hu and Jaspers (2007) have shown that consumers buying health food value its quality more that quantity and are more likely to think practically when buying clothes, keeping their utilitarian goals in mind, that is emphasizing product usefulness and the necessity to satisfy specific needs.

Research work on emotional factors (Donovan et al., 1994; Sherman et al., 1997) has proven that when consumers making purchases feel happy in the environment where they are buying, they are willing to stay longer at the store, buy more and spend more. Similarly, the form and quality of the provided services significantly affect the decisions made by consumers. Customers prefer to be perceived as individuals. This is why helpful and friendly store personnel who are simply nice and sensitive to customers' needs will contribute to the effect that shopping will be pleasant (Lumpkin, 1985; Hu \& Jaspers, 2007).

Goodwin and McElwee (1999) observed that consumers were more willing to buy at stores representing higher quality of service than at other stores, even if prices were slightly higher. Liaw (2007) proves that visual elements of the place of purchasing such as its design and the way the store employees are perceived may have a positive influence on emotions associated with buying, consumer behavior, and consumer satisfaction. This fact served as the basis for formulating the following hypotheses:

$\mathrm{H} 1$ : Personal factors such as needs, lifestyles, and values have a significant influence on the choice of the shopping mall as a place of shopping for goods and services.

$\mathrm{H}$ 2: Emotional factors such as store service quality and leisure experiences have a significant influence on the choice of the shopping mall as a place of shopping for goods and services.

Another key determinant from the perspective of consumers seems to be the location of a shopping mall. Its convenient location with respect to the customers' place of residence and with respect to other main shopping and service establishments, interior store layout, design and ambience (including 'nice' colors and interesting lighting) (Moschis et al., 1995) as well as a large number of businesses such as companies and retailers 
operating at a shopping mall may determine a specific consumer behavior. Petermans and Van Cleempoel (2010) emphasize that people who shop for goods and services offered at shopping malls also pay attention to immaterial aspects, that is a comfortable, friendly and aesthetic environment, which inspires shopping and relaxation.

According to Meneely et al.(2009), another matter that is important to consumers is the availability of parking space that is both safe and easy to get to. This fact was the basis for formulating the next two hypotheses:

H3: Mall environment (location, design, safety and security) has a significant influence on the choice of shopping mall as a place of shopping for goods and services.

H4: Situational factors such as prices of goods, quality goods, variety of assortment and parking facilities have a significant influence on the choice of a shopping mall as a place of shopping for goods and services.

In the process of further investigation, a theoretical research model was developed - the structural equation model (SEM) - which was subsequently used for the verification of the hypotheses that were set forth in this study: $\mathrm{H} 1, \mathrm{H} 2, \mathrm{H} 3$ and $\mathrm{H} 4$. The four factors specified in the model, which were exogenous latent variables, namely personal factors (PF), emotional factors (EF), mall environment (ME), and situational factors (SF) were assigned an appropriate set of observable variables (called indicators) that further characterized them. In addition, the endogenous latent variable was described using eight observable variables (Fig. 1, Tab. 2). It was assumed in the SEM model that observable variables serve as a reflection of corresponding latent variables (reflective relationships).

\section{Empirical analysis}

\section{Samples and research methods}

In order to test the research hypotheses used in the study, a direct market survey was conducted in Poland (Warsaw, Kraków, Wrocław, Poznań), during the period from February 2019 to June 2019 using a questionnaire as a research tool. The method used in this research was the PAPI (Paper \& Pen Personal Interview), that is a direct interview with the

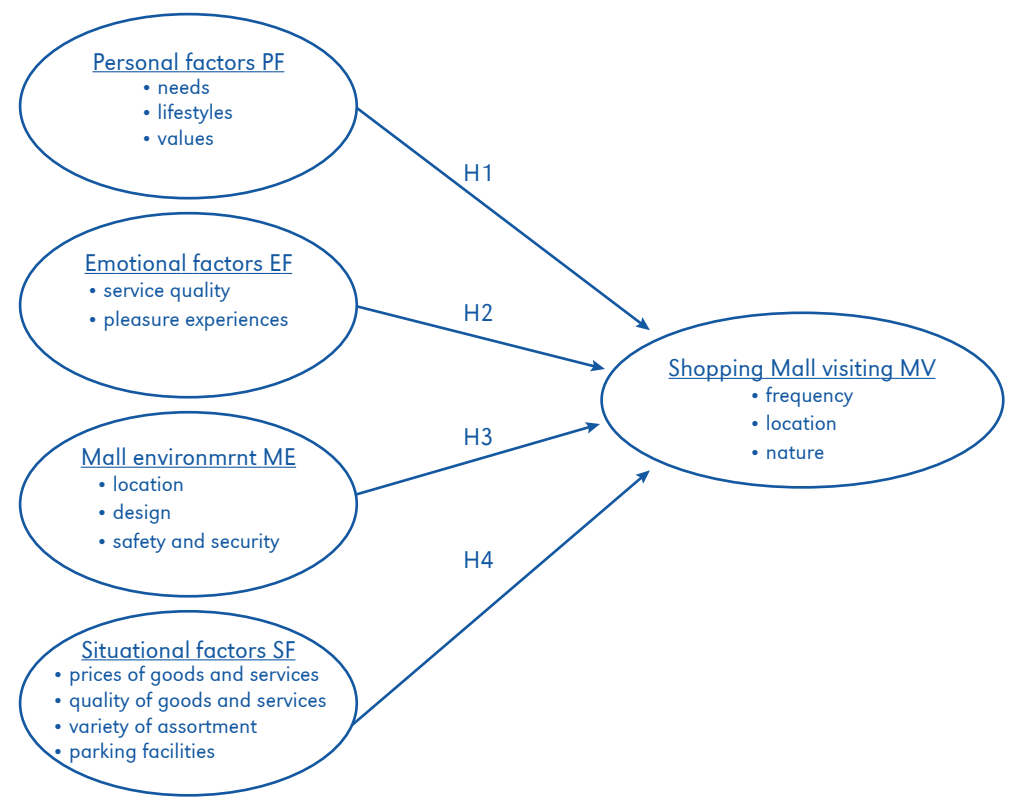

Figure 1. Proposed theoretical research model - factors determining shopping mall visits 
use of a questionnaire. The questionnaire consisted of 26 questions and included items that relate to the variables in the conceptual model. At first the authors tested 35 items concerned personal factors (PF), emotional factors (EF), mall environment (ME), situational factors (SF) and shopping mall visiting (MV) in a pilot study. It involved forty six students from the Pedagogical University of Krakow. In order to differentiate the age of the respondents, there were 23 full-time students and 23 extramural students. They had to complete the questionnaire and comment on the clarity of the items. The respondents did not experience any problems with the clarity of the items.

A total of 550 interviewees participated in the main research effort. Almost 70\% of the survey participants were women, and slightly over $30 \%$ were men. They were young people, 18-39 years of age, out of whom more than three fourths (75.7\%) were people who were 30 years old or younger. The respondents were primarily students who were also working professionals (almost 35\%) or working professionals (almost 30\%) who were high school $(52.4 \%)$ or college $(45.5 \%)$ graduates (Tab. 1).

Almost one third of survey participants declared that they have enough money to cover all expenses, with no need to count every penny. A similar share of survey participants (25\%) spent at least $200 \mathrm{PLN}$ on one visit to the shopping mall. However, a substantial share of survey participants, or more precisely 58.6\%, declared they are thrifty and spend money in a conservative manner. In spite of that almost $34 \%$ of the interviewed spent about 100 to 200 PLN on one visit to the mall.

Table1. Characteristics of survey participants

\begin{tabular}{|c|c|c|c|}
\hline & Attribute $(\mathrm{N}=550)$ & $\begin{array}{l}\text { Number } \\
\text { of survey }\end{array}$ & $\begin{array}{l}\text { Percentage }[\%] \\
\text { of the statistical }\end{array}$ \\
\hline Gender & women & 384 & 69.8 \\
\hline & men & 166 & 30.2 \\
\hline Age Group & $18-24$ & 342 & 62.2 \\
\hline & $25-29$ & 74 & 13.5 \\
\hline & $30-34$ & 70 & 12.7 \\
\hline & $35-39$ & 64 & 11.6 \\
\hline Education & elementary school, trade school & 12 & 2.2 \\
\hline & high school & 288 & 52.4 \\
\hline & college & 250 & 45.5 \\
\hline Current occupation & working & 162 & 29.5 \\
\hline & unemployed & 16 & 2.9 \\
\hline & student & 190 & 34.5 \\
\hline $\begin{array}{l}\text { How the survey } \\
\text { participant manages }\end{array}$ & $\begin{array}{l}\text { My income suffices for all my expenses with } \\
\text { no need to count every penny }\end{array}$ & 166 & 30.2 \\
\hline his/her income & $\begin{array}{l}\text { I am thrifty and thanks to that I have enough } \\
\text { money for everything }\end{array}$ & 188 & 34.2 \\
\hline & $\begin{array}{l}\text { I am thrifty and spend conservatively in order } \\
\text { to save for major purchases }\end{array}$ & 134 & 24.4 \\
\hline & $\begin{array}{l}\text { I have enough money for current needs only (food, } \\
\text { clothing, rent) }\end{array}$ & 50 & 9.1 \\
\hline & $\begin{array}{l}\text { I do not have enough money, even for my current } \\
\text { needs, and I have to borrow or use may savings }\end{array}$ & 12 & 2.2 \\
\hline
\end{tabular}




\section{Structural equation model test}

For five operationalized latent variables, a total of 35 observable variables and also 35 DELTA measurement error values were identified. All the latent variables, observable variables (so-called manifest variables) describing them, and factor loadings and DELTA measurement errors are shown in Table 2.

The model parameters used in the present study are significant at the significance level $p=0.0001$. The results of estimation of parameters of the hypothetical model indicate that 33 out of 35 obtained path coefficients (factor regression) are statistically significant and confirm all four stated hypotheses. Indicators that do not describe the proposed model are: MV_AV_1 and MV_AV_2, which are associated with the construct 'MV_Shopping mall visits'. Since the proposed model was insufficiently fit, it was modified. Paths associated with coefficients that were not statistically significant as well as corresponding variances of independent (exogenous, predictor) variables were removed.

Next, an analysis of the measures of reliability of fit of the modified model of structural equations, and of the measures of goodness of fit of the structural equation model being tested, was performed. Reliability statistics such as Joreskog's RHO and Cronbach's

Table 2. Structural parameters of the proposed model of structural equations

\begin{tabular}{|c|c|c|c|c|c|}
\hline $\begin{array}{l}\text { Con- } \\
\text { structs }\end{array}$ & Indicators & M & SD & $\begin{array}{c}\text { Factor } \\
\text { regression }\end{array}$ & DELTA \\
\hline \multirow{7}{*}{ 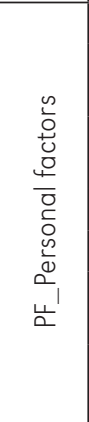 } & PF_N_1 - I prefer the shopping mall as a place for purchasing. & 3.6 & 0.9 & 0.306 & 0.694 \\
\hline & $\begin{array}{l}\mathrm{PF} \_N_{-} 2 \text { - The shopping mall is a place where one can spend } \\
\text { spare time and shop at the same time. }\end{array}$ & 3.4 & 1.2 & 0.808 & 0.670 \\
\hline & $\begin{array}{l}\text { PF_LS_3 - Shopping malls are places where people my age } \\
\text { spend their spare time. }\end{array}$ & 2.8 & 1.1 & 0.935 & 0.336 \\
\hline & PF_LS_4 - My friends spend their spare time at shopping malls & 2.9 & 1.1 & 0.890 & 0.409 \\
\hline & PF_LS_5 - Spending time at a shopping mall is a new lifestyle. & 2.7 & 1.2 & 0.772 & 0.782 \\
\hline & $\begin{array}{l}\text { PF_V_6 - At a shopping mall I can see attention-grabbing } \\
\text { displays and learn something interesting. }\end{array}$ & 2.8 & 1.0 & 0.614 & 0.711 \\
\hline & $\begin{array}{l}\mathrm{PF} \mathrm{V}_{-} 7 \text { - There is something interesting that is worth seeing } \\
\text { occurring frequently at a shopping mall. }\end{array}$ & 2.7 & 1.0 & 0.622 & 0.576 \\
\hline \multirow{5}{*}{ 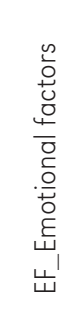 } & EF_SQ_1 - I trust the sales people working at shopping malls. & 2.9 & 1.0 & 0.572 & 0.652 \\
\hline & $\begin{array}{l}\text { EF_SQ_2 - I am fully satisfied with the quality of service } \\
\text { at shopping malls }\end{array}$ & 3.3 & 0.9 & 0.458 & 0.567 \\
\hline & $\begin{array}{l}\text { EF_PE_3 - I prefer spending my spare time at a shopping mall, } \\
\text { because I feel comfortable here. }\end{array}$ & 3.1 & 1.1 & 0.814 & 0.445 \\
\hline & $\begin{array}{l}\text { EF_PE_4 - Nice thoughts come to mind when looking at these } \\
\text { types of places. }\end{array}$ & 3.1 & 1.0 & 0.783 & 0.450 \\
\hline & $\begin{array}{l}\text { EF_PE_5 - Friendly and helpful employees create a nice } \\
\text { atmosphere. }\end{array}$ & 3.3 & 0.9 & 0.437 & 0.644 \\
\hline \multirow{5}{*}{ 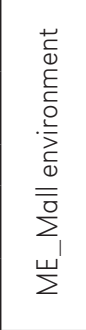 } & $\begin{array}{l}\text { ME_L_1 - I like the shopping mall's location, because I can get } \\
\text { here by public transportation without any problems. }\end{array}$ & 4.0 & 0.8 & 0.471 & 0.425 \\
\hline & $\begin{array}{l}\text { ME_L_2 - Shopping malls are conveniently located, which } \\
\text { makes them easy to get to. }\end{array}$ & 3.9 & 0.9 & 0.583 & 0.404 \\
\hline & ME_D_3 - I like that shopping malls are nicely decorated. & 3.3 & 1.0 & 0.679 & 0.459 \\
\hline & $\begin{array}{l}\text { ME_D_4 - Shopping malls are large and give you the feeling } \\
\text { of ample space and freedom. }\end{array}$ & 3.3 & 1.1 & 0.642 & 0.718 \\
\hline & $\begin{array}{l}\text { ME_D_5 - I value the fact that at shopping malls there are } \\
\text { special areas, where one may rest or work. }\end{array}$ & 3.0 & 1.1 & 0.414 & 1.037 \\
\hline
\end{tabular}




\begin{tabular}{|c|c|c|c|c|c|}
\hline $\begin{array}{l}\text { Con- } \\
\text { structs }\end{array}$ & Indicators & M & SD & $\mid \begin{array}{c}\text { Factor } \\
\text { regression }\end{array}$ & DELTA \\
\hline \multirow{9}{*}{ 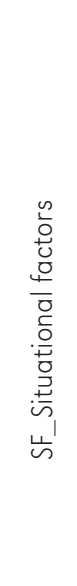 } & $\begin{array}{l}\text { SF_SS_1 - Security personnel at shopping malls provide a sat- } \\
\text { isfactory level of security. }\end{array}$ & 3.2 & 0.9 & 0.489 & 0.529 \\
\hline & $\begin{array}{l}\text { SF_SS_2 - Security at shopping malls is usually helpful, when } \\
\text { I need it. }\end{array}$ & 3.2 & 0.9 & 0.465 & 0.529 \\
\hline & $\begin{array}{l}\text { SF_PG_3 - Products offered for sale at shopping malls are } \\
\text { available at attractive prices. }\end{array}$ & 3.4 & 1.0 & 0.606 & 0.562 \\
\hline & $\begin{array}{l}\text { SF_PG_4 - I gladly take advantage of the promotions and } \\
\text { discounts offered by stores at shopping malls. }\end{array}$ & 3.8 & 0.9 & 0.402 & 0.741 \\
\hline & $\begin{array}{l}\text { SF_PG_5 - Prices of products at shopping malls are lower than } \\
\text { at other retail establishments. }\end{array}$ & 3.2 & 1.0 & 0.532 & 0.706 \\
\hline & $\begin{array}{l}\text { SF_PG_6 - Many establishments offer products or services } \\
\text { I can afford. }\end{array}$ & 3.6 & 0.8 & 0.444 & 0.478 \\
\hline & SF_QG_7 - Products offered for sale are of good quality. & 3.3 & 0.9 & 0.570 & 0.575 \\
\hline & SF_QG_8 - Services provided are of satisfactory quality. & 3.4 & 0.8 & 0.530 & 0.383 \\
\hline & $\begin{array}{l}\text { SF_P_9 - I can use the parking lot and I do not have to worry } \\
\text { about the availability of parking space. }\end{array}$ & 3.3 & 1.1 & 0.558 & 0.854 \\
\hline \multirow{9}{*}{ 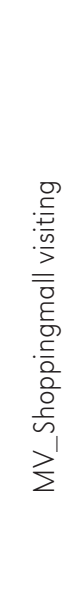 } & $\begin{array}{l}\text { SF_P_10 - Parking facilities have a sufficient number of park- } \\
\text { ing spots. }\end{array}$ & 3.6 & 1.2 & 0.508 & 1.090 \\
\hline & MV_F_1 - I visit a shopping mall at least once a week. & 2.2 & 1.1 & 1 & 1.126 \\
\hline & MV_F_2 - I spend at least one hour at a shopping mall. & 3.1 & 1.0 & 0.378 & 0.930 \\
\hline & $\begin{array}{l}\text { MV_AV_3 - At a shopping mall I can buy all the products } \\
\text { I need in one place. }\end{array}$ & 3.7 & 1.0 & 2.474 & 0.782 \\
\hline & $\begin{array}{l}\text { MV_AV__ } 4 \text { - The broad and diversified offering of products for } \\
\text { sale at shopping malls fully fulfills my needs. }\end{array}$ & 3.4 & 1.0 & 2.904 & 0.722 \\
\hline & $\begin{array}{l}\text { MV_AV_5 - Shopping malls offer a broad range of services, } \\
\text { which fully fulfills my needs. }\end{array}$ & 3.3 & 1.0 & 3.215 & 0.732 \\
\hline & $\begin{array}{l}\text { MV_AV_6 - I like to spend time at shopping malls because } \\
\text { of a wide choice of entertainment activities offered. }\end{array}$ & 2.9 & 1.0 & 4.017 & 0.506 \\
\hline & $\begin{array}{l}\text { MV_NAT_7 - I like the food choices offered in restaurants } \\
\text { located at shopping malls. }\end{array}$ & 3.4 & 1.0 & 3.734 & 0.559 \\
\hline & $\begin{array}{l}\text { MV_NAT_8 - It is a place, where I can spend my spare time } \\
\text { with pleasure. }\end{array}$ & 3.0 & 1.1 & 4.363 & 0.604 \\
\hline
\end{tabular}

Source: Authors' own work, with the use of the SEPATH module of STATISTICA13 software.

Alpha in the case of the considered exogenous latent variables produced a value greater than 0.7 , which signifies a relatively good reliability of the scale. The AVE index takes on values of less than 0.7 only in the case of two variables (ME, SF). The analyzed index values show that particular sets of observable variables measure the investigated pattern relatively well, and in the case of the ME, SF variables require further consideration. However, the model fit indices, Bentler-Bonett index (0.551) and Steigern-Lind's RMSEA (0.125), indicated the necessity of rejecting the proposed model.
In connection with the above findings, the model was tested again; it was finetuned and restated. Due to the likely occurrence of a 'halo effect' and 'mindset effect', one of the key constructs as well as selected indicators describing constructs specified in the studied model were removed. The model so modified was statistically tested again.

Table 4 lists the descriptive statistics for the four factors (latent variables) and sixteen observable variables that derive from the literature review and results from focus groups. The frequency distribution 
Table 3. Reliability of fit measures of the modified model of structural equations

\begin{tabular}{|c|c|c|c|c|c|}
\hline $\begin{array}{c}\text { Con- } \\
\text { structs }\end{array}$ & Indicators & $\begin{array}{c}\text { Factor } \\
\text { regression }\end{array}$ & DELTA & Alpha & $\mathrm{RHO}$ \\
\hline & PF_N_2 - The shopping mall is a place, where you can spend & 0.805 & 0.675 & \multirow{7}{*}{0.850} & \multirow{7}{*}{0.897} \\
\hline$\stackrel{\circ}{\circ}$ & у & & & & \\
\hline$\underset{0}{0}$ & $\begin{array}{l}\text { PF_LS_3 - Shopping malls are places, where people my age } \\
\text { spend spare time. }\end{array}$ & 0.945 & 0.318 & & \\
\hline $\begin{array}{ll}0 \\
\text { C } \\
\text { c }\end{array}$ & PF__LS_4 - My friends spend spare time at shopping malls & 0.928 & 0.339 & & \\
\hline$\stackrel{\bar{\omega}_{1}}{2}$ & PF_LS_5 - Spending time at a shopping mall is a new lifestyle. & 0.729 & 0.847 & & \\
\hline 㟧 & $\begin{array}{l}\text { EF_PE_4 - Nice thoughts come to mind when looking at these } \\
\text { types of places. }\end{array}$ & 0.614 & 0.687 & & \\
\hline \multirow{3}{*}{ 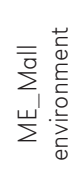 } & $\begin{array}{l}\text { ME_L_2 - Shopping malls are conveniently located, which } \\
\text { makes it easy to get there. }\end{array}$ & 0.466 & 0.542 & & \\
\hline & ME_D_3 - Shopping malls are nicely decorated and I like it. & 0.699 & 0.405 & \multirow[t]{2}{*}{0.690} & \multirow[t]{2}{*}{0.820} \\
\hline & $\begin{array}{l}\text { ME_D_4 - Shopping malls are large and give you a feeling } \\
\text { of ample space and freedom. }\end{array}$ & 0.736 & 0.581 & & \\
\hline \multirow{4}{*}{ 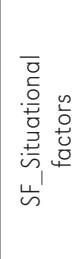 } & $\begin{array}{l}\text { SF_PG_3 - Products offered for sale at shopping malls are } \\
\text { attractively priced. }\end{array}$ & 0.674 & 0.475 & \multirow{4}{*}{0.744} & \multirow{4}{*}{0.725} \\
\hline & $\begin{array}{l}\text { SF_PG_5 - Prices of products at shopping malls are lower than } \\
\text { at other retail establishments. }\end{array}$ & 0.507 & 0.703 & & \\
\hline & SF_QG_7 - Products offered for sale are of good quality. & 0.576 & 0.599 & & \\
\hline & $\begin{array}{l}\text { SF_P_9 - I can use the parking lot and I do not have to worry } \\
\text { about the availability of parking space. }\end{array}$ & 0.495 & 0.920 & & \\
\hline \multirow{4}{*}{ 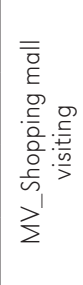 } & $\begin{array}{l}\text { MV_AV_4 - The broad and diversified offering of products for } \\
\text { sale at shopping malls fully fulfills my needs. }\end{array}$ & 1 & 0.789 & \multirow{4}{*}{0.746} & \multirow{4}{*}{0.936} \\
\hline & $\begin{array}{l}\text { MV_AV_5 - Shopping malls offer a broad range of services, } \\
\text { which fully fulfill my needs. }\end{array}$ & 1.139 & 0.798 & & \\
\hline & $\begin{array}{l}\text { MV_AV_6 - I like to spend time at shopping malls, because } \\
\text { of the broad choice of entertainment activities offered. }\end{array}$ & 1.608 & 0.485 & & \\
\hline & $\begin{array}{l}\text { MV_NAT_7 - I like the food choices offered in restaurants } \\
\text { located at shopping malls. }\end{array}$ & 1.437 & 0.578 & & \\
\hline
\end{tabular}

Source: Authors' own work, with the use of the SEPATH module of STATISTICA13 software.

shows that for all the factors, most survey participants provided positive ratings (4-5). The most positively rated factors were ME, MV, and SF. This suggests that shopping malls should be sensitive to the needs of younger customers regarding convenient location (ME_L_2) and a large trading floor space, giving a sense of ample breathing room and freedom (ME_D_4). Moreover, a broad and diversified range of food offered for sale through mall restaurants (MV_NAT_7) and the mall product range that is offered for sale (MV_AV_4) fully satisfy the needs of younger consumers. The interviewees also confirmed that products available at shopping malls are offered for sale at attractive prices (SF_PG_3) and represent a good level of quality (SF_QG_7). What is also important to the interviewed in the survey is the possibility of finding a parking space without worrying about its availability (SF_P_9).

Reliability statistics such as Joreskog's $\mathrm{RHO}$ and Cronbach's Alpha, in the case of most exogenous latent variables, had values greater than 0.7 (only in the case of the 'ME_Mall environment' construct the index value was slightly less than 0.7 ), which signifies a relatively good reliability of the scale. The analyzed index values show that the studied sets of observable variables measure the investigated pattern relatively well. 
Table 4. Frequency distribution for the studied factors $(n=550)$

\begin{tabular}{|l|c|c|c|c|c|c|}
\hline & Negative & $\%$ & Neutral & $\%$ & Positive & $\%$ \\
\hline PF N_2 & 132 & 24.0 & 84 & 15.3 & 334 & 60.7 \\
PF LS_3 & 190 & 34.5 & 212 & 38.5 & 148 & 26.9 \\
PF LS_4 & 198 & 36.0 & 152 & 27.6 & 20.0 & 36.4 \\
PF LS_5 & 238 & 43.3 & 144 & 26.2 & 168 & 30.5 \\
EF PE_4 & 156 & 28.4 & 184 & 33.5 & 210 & 38.2 \\
PF & 182.8 & 33.2 & 155.2 & 28.2 & 212 & 38.5 \\
ME L_2 & 42 & 07.6 & 74 & 13.5 & 434 & 78.9 \\
ME D_3 & 90 & 16.4 & 212 & 38.5 & 248 & 45.1 \\
ME D_4 & 122 & 22.2 & 156 & 28.4 & 272 & 49.5 \\
ME & 84.7 & 15.4 & 147.3 & 26.8 & 318.0 & 57.8 \\
SF PG_3 & 106 & 19.3 & 158 & 28.7 & 286 & 52.0 \\
SF PG_5 & 326 & 59.3 & 130 & 23.6 & 94 & 17.1 \\
SF QG_7 & 94 & 17.1 & 182 & 33.1 & 274 & 49.8 \\
SF P_9 & 124 & 22.5 & 120 & 21.8 & 306 & 55.6 \\
SF & 162.5 & 29.5 & 147.5 & 26.8 & 240.0 & 43.6 \\
MV AV_4 & 102 & 18.5 & 144 & 26.2 & 304 & 55.3 \\
MV AV_5 & 128 & 23.3 & 132 & 24.0 & 290 & 52.7 \\
MV AV_6 & 208 & 37.8 & 176 & 32.0 & 166 & 30.2 \\
MV_NAT_7 & 116 & 21.1 & 112 & 20.4 & 322 & 58.5 \\
MV & 138.5 & 25.2 & 141.0 & 25.6 & 270.5 & 49.2 \\
\hline
\end{tabular}

Source: Authors' own work, with the use of the SEPATH module of STATISTICA13 software.

The fit indices used in the study indicate a relatively acceptable level of model fit (Tab. 5). The value of the root mean square error of approximation (RMSEA $=0.08$ ) is at its lower bound. The goodness of fit Gamma index as well as the GFI both indicate that about $0.88 \%$ of actual covariances are

Table 5. Goodness of fit measures of the structural equation model being tested

\begin{tabular}{|l|c|}
\hline \multicolumn{2}{|c|}{ Goodness of fit measures } \\
\hline Chi-square / degrees of freedom & $324.369 / 93$ \\
Chi-square $p$ & 0.000 \\
Joreskog's GFI & 0.877 \\
Joreskog's AGFI & 0.820 \\
Bentler-Bonett index & 0.854 \\
Steigern-Lind RMSEA & 0.080 \\
Gamma population index & 0.890 \\
\hline
\end{tabular}

Source: Authors' own work, with the use of the SEPATH module of STATISTICA13 software. explained by the developed model. The goodness of fit indices: the AGFI and the Bentler-Bonett index had a slightly lower value.

\section{Discussion}

The main goal of this paper was to identify the key determinants influencing young consumer decisions regarding the choice of shopping malls as places of purchasing and use of services. A theoretical model was developed based on the available literature on the subject. The model comprised indicators describing main determinants. The model was tested and subsequently modified using structural modeling (SEM, path diagram). Data obtained through empirical research were then used in the modeling process. Statistically significant relationships were observed between 3 out of 4 isolated factor groups: personal factors (PF), shopping mall environment (ME) and situational factors (SF), 
and the unique behavior of the young consumer who feels motivated to visit a shopping mall (shopping mall visiting MV).

It may be stated, based on the conducted statistical analyses, that all coefficients in the modified model of structural equations were statistically significant. The modified model may be regarded as relatively satisfactory in light of the considered indices of fit. This permitted making a positive verification of 3 out of the 4 initially stated hypotheses, namely hypotheses $\mathrm{H} 1, \mathrm{H} 3$, and $\mathrm{H} 4$.

According to the research participants' responses, personal factors (including consumer perceived needs, lifestyles and values), mall environment (location, design, safety and security), and situational factors (prices of goods, quality of goods, variety of assortment and parking facilities) significantly influence consumer behavior and consumer choices at shopping malls.

The authors of this work observed significant relationships between factors such as personal factors, mall environment, situational factors, and shopping mall visiting among younger consumers. Furthermore, in the opinions expressed by young shoppers, the mall environment and situational factors were significantly higher rated than personal factors. In addition, the authors found that the young shoppers' personal factors section needs improvement.

To sum up, the fact that there is no positive verification of the $\mathrm{H} 2$ hypothesis concerning emotional factors (EF) and the lower importance of personal factors (PF) in relation to the other two factors is puzzling. The explanation here may be that consumers mainly value convenience, comfort and an attractive and wide assortment. This is also confirmed by the research of other authors (Borusiak et al., 2018; Bawa et al., 2019; Klapilová Krbová, 2016; Kunc et al., 2012). On the other hand, the surveyed consumers are not emotionally attached to the shopping center they visit, perceiving it only as a place to perform necessary duties, not a pleasure. They do not associate the fact of being in a shopping center with a feeling of pleasure, spending free time and meeting friends (or they do not admit it). A similar phenomenon was also observed in relation to mature shoppers (Walker \& Mesnard, 2012). However, the respondents relatively often use the available services in the field of entertainment, sports and recreation. This is also confirmed by the authors' previous research conducted among customers of Kraków shopping centers (Szymańska \& Płaziak, 2017).

In the opinion of the authors, it is justified to undertake further research on the impact of emotional factors (EF) and personal factors (PF) on the decisions of young consumers. The reluctance to display emotions could have influenced the marginalization of the above-mentioned factors in the presented research results. For this purpose, qualitative studies such as in-depth interview and focus group interview should be used to verify the role of these two factors.

\section{Practical implications for mall management}

A paradigm shift may be required when retail chains are being designed for the young generation. Retailers and shopping mall managers should keep that in mind if they really want to cater to the population segment of young shoppers and tap into their spending power. They should improve the atmosphere in the shopping mall, which will be favorable not only in doing shopping, but will also encourage young consumers to spend their spare time at the shopping mall. The management should broaden the range of what a shopping mall has to offer to include not only an attractive product assortment offered for sale at good prices, but also an extended service offering that involves cultural, recreational, entertainment, spa and beauty, and other cultural event type of offering, which will make spending time at the mall more attractive.

Interesting displays, cultural events, excellent food with attractive pricing on the restaurant menu, or workspaces for freelancers will also attract the more demanding young customers. An attention should also be paid 
to the necessity of improvement in the quality of customer service and to increasing the level of consumer trust with respect to mall personnel as well as efficient mall security. Our research results suggest that young shoppers want high quality products at good prices. Furthermore, the results suggest that young people look for leisure experiences at shopping malls as places where they can enjoy themselves.

Young shoppers are an important market segment. Store managers need to monitor them continuously because of their potential purchasing power. Shopping mall managers need their sales and should focus on the personal preferences of young shoppers as well as on the store environment and reasonably priced quality merchandise in order to increase the number of visits to shopping malls.

Implications that relate to the studied model indicate that the visiting of shopping malls is the culmination of a variety of factors that shopping mall managers need to address. These factors are especially important when they cater to highly critical and demanding younger consumers.

Editors' note:

Unless otherwise stated, the sources of tables and figures are the authors', on the basis of their own research.

\section{References}

Aktas, G. (2012). Sustainable design proposals in shopping center public interiors. International Journal of Energy and Environment. 1(6), 109-0116.

Aldridge, A. (2006). Konsumpcja (Translator: M. Żakowski.). Warszawa: Sic!. (Original work published 2003).

Arnold, M.J., Reynolds, K.E. (2003). Hedonic shopping motivations, Journal of Retailing, 79(2), 259-268. https://doi.org/10.1016/S0022-4359(03)00007-1

Baker, G., Funaro, B. (1951). Shopping centers: Design and operation. New York: Van Nostrand Reinhold Company.

Baker, J., Wakefield, K.L. (2012). How consumer shopping orientation influences perceived crowding, excitement, and stress at the mall. Journal of the Academy of Marketing Science. 40(6), 791-806. https://doi.org/10.1007/s11747-011-0284-z

Bawa, R., Sinha, A.K., Kant, R. (2019). Emerging mall culture and shopping behavior of young consumers. Advances in Anthropology, 9(3), 125-150. https://doi.org/10.4236/aa.2019.93010

Boeckl, M. (1995). Visionäre und Vertriebene. Österreichische Spuren in der modernen amerikanischen Architektur. Berlin: Ernst und Sohn.

Borusiak, B., Pierański, B., Florek, M., Mikołajczyk, J. (2018). Critical factors of shopping centre attractiveness in the opinions of students - the case of Poznan. Handel Wewnętrzny, 1(372), 186-202.

Chase, J. (1991). The role of consumerism in American architecture. Journal of Architectural Education, 44(4), 211-224. https://doi.org/10.1080/10464883.1991.11102697

Chebat, J-C., Michon, R., Haj-Salem, N., Oliveira, S. (2014). The effects of mall renovation on shopping values, satisfaction and spending behaviour, Journal of Retailing and Consumer Services, 21(4), 610-618. https://doi.org/10.1016/j.jretconser.2014.04.010

Clarke, D.B. (2003). The consumer society and the postmodern city. London: Routledge. https://doi.org/10.4324/9780203414149

Cohen, N. (2002). American marketplace: The history of shopping centers. Lyme, Connecticut: Greenwich Publishing Group. 
Coleman, P. (2006). Shopping environments: Evolution, planning and design London: Architectural Press.

Dawson, J.A., Lord, J.P. (1985). Shopping centre development: Policies and prospects. New York: Routledge.

Davis, T.C. (1991). Theatrical antecedents of the mall that ate downtown. Journal of Popular Culture, 24(4), 1-15. https://doi.org/10.1111/j.0022-3840.1991.2404_1.x

Denis, Ch. (2005). Objects of desire: Consumer behaviour in shopping centre choices. London: Palgrave Macmillan. https://doi.org/10.1057/9780230509481

Dębek, M. (2015). What drives shopping mall attractiveness? Polish Journal of Applied Psychology, 13(1), 67-118. https://doi.org/10.1515/pjap-2015-0026

Donovan, R.J., Rossiter, J.R., Marcoolyn, G., Nesdale, A. (1994). Store atmosphere and purchasing behavior. Journal of Retailing, 70(3), 283-294. https://doi.org/10.1016/0022-4359(94)90037-X

Dowling, R.W. (1943). Neighborhood shopping centers. Architectural Forum, 79.

Dowling, R.W. (1944). Shopping centers - a neighborhood necessity. Urban Land, 3.

El-Adly, M.I., Eid, R. (2016). An empirical study of the relationship between shopping environment, customer perceived value, satisfaction, and loyalty in the UAE malls context. Journal of Retailing and Consumer Services, 31, 217-227. https://doi.org/10.1016/j.jretconser.2016.04.002

Eppli, M., Benjamin, J.D. (1994). The Evolution of shopping center research: A review and analysis. Journal of Real Estate Research, 9(1), 5-32. https://doi.org/10.1080/10835547.1994.12090737

Feiss, C. (1940). Community shopping centers. Architectural Record, 6.

Feng, L., Xiao-Ting, S. (2015). Research on exploring the formation factors of youth entrepreneurship satisfaction and behavior intention. Acta Oeconomica, 65(S2), 279-293. https://doi.org/10.1556/032.65.2015.s2.21

Fisher, H.T. (1950). Can main street compete? The American City, 65(10).

Frieden, B.J., Sagalyn, L.B. (1991). Downtown, inc.: How America rebuilds cities. Cambridge: MIT Press.

Garreau, J. (1991). Edge city: Life on the new frontier. New York: Anchor.

Górka, Z., Trzepacz, P. (2006). Węzły autostrady A4 jako czynniki rozwoju oraz przemian w zagospodarowaniu peryferyjnych osiedli Krakowa. In I. Jażdżewska (Ed.), Nowe przestrzenie w miastach. Ich organizacja i funkcje (pp. 345-351). Łódź: Wydawnictwo Uniwersytetu Łódzkiego.

Gruen, V. (1943). Shopping Center. Architectural Forum, 78.

Gruen, V., Smith, L.P. (1952). Shopping centers: The new building type. Progressive Architecture, 33.

Haoying, H., Noman, S., Thuy, N., Jinsoo, H., Muhammad, A. (2019). Exploring the features of sustainable urban form and the factors that provoke shoppers towards shopping malls. Sustainability, 11(17), 4798. https://doi.org/10.3390/su11174798

Hardwick, M.F. (2004). Mall maker: Victor Gruen, architect of an American Dream. Philadelphia: University of Pennsylvania Press.

Hendershott, P.H., Hendershott, R.J., Hendershott, T.J. (2001). The future of virtuall malls. Real Estate Finance, 18(1), 25-32.

Hu, H., Jaspers, C.R. (2007). A Qualitative Study of Mall Shopping Behaviors of Mature Consumers. Journal of Shopping Center Research, 14(1), 17-38.

Jałowiecki, B. (2005). Przestrzeń ludyczna - nowe obszary metropolii. Studia Regionalne i Lokalne, 3(21), 5-19.

Kelley, E.J. (1956). Shopping centers. Locating controlled regional centers, The Eno Foundation for Highway Traffic Control, Saugatuck.

Klapilová Krbová, P. (2016). Generation Y attitudes towards Shopping: A comparison of the Czech Republic and Slovakia. Journal of Competitiveness, 8(1), 38-54. https://doi.org/10.7441/joc.2016.01.03

Kramer, R. (1996). Ethik des Geldes. Berlin: Verlag Duncker und Hublot. 
Kuc-Słuszniak, B. (2008a). Targowisko różnorodności - targowisko próżności. Współczesne centrum handlowe w przestrzeni miejskiej. Czasopismo Techniczne, 3-A, 135-141.

Kuc-Słuszniak, B. (2008b). Nowe w starym - centra handlowe w Rybniku. Czasopismo Techniczne, 105(6-A), 393-399.

Kunc, J., Tonev, P., Szczyrba, Z., Frantál, B. (2012). Shopping centres and selected aspects of shopping behaviour (Brno, the Czech Republic), Geographia Technica, 2, 39-51.

Kusumowidagdo, A., Sachari, A., Widodo, P. (2015). Visitors' perception towards public space in shopping center in the creation sense of place. Procedia - Social and Behavioral Sciences, 184, 266-272. https://doi.org/10.1016/j.sbspro.2015.05.090

Liaw, G.F. (2007). The influence of multiple store environment cues on shopping mood and patronage satisfaction. Paper read at 7th Global Conference on Business and Economics. Rome, Italy.

Lillibridge, R.M. (1948). Shopping centers in urban redevelopment. Land Economics, 24(2), 137-160.

Longstreth, R. (1997). City center to regional mall: Architecture, the automobile, and retailing in California,1920-1950. Cambridge: MIT Press.

Lowe, M.S. (2000). Britain's regional shopping centres: New urban forms? Urban Studies, 37, 261-74. https://doi.org/10.1080/0042098002186

Lumpkin, J.R. (1985). Shopping orientation segmentation of the elderly consumer. Journal of the Academy of Marketing Science, 13(2), 271-289. https://doi.org/10.1007/BF02729720

Massagali, M.K. (2000). E-tail vs retail the future of the dowtown regional shopping mall. Cambridge: Massachusetts Instytute of Technology.

Meneely, L., Burns, A., Strugnell, Ch. (2009). Age associated changes in older consumers retail behaviour. International Journal of Retail \& Distribution Management, 37(12), 1041-1056. https://doi.org/10.1108/09590550911005010

Merts, J.E. (1949). The shopping center - a new trend in retailing. Journal of Marketing, 13. https://doi.org/10.1177/002224294901300317

Millan, E.S., Howard, E. (2007). Shopping for pleasure? Shopping experiences of Hungarian consumers. International Journal of Retail \& Distribution Management, 35(6), 474-487. https://doi.org/10.1108/09590550710750340

Moschis, G.P., Sneath, J.Z., Mathur, A. (1995). Existing retail strategies and older consumers. Journal of Shopping Centre Research, 2(1), 48-63.

Mumford, L. (1961). The city in history. London: Penguin Book Group.

Naisbitt, J. (1997). Megatrendy. Dziesięć nowych kierunków zmieniających nasze życie. Poznań: Zysk i S-ka.

Pedreschi, R. (2000). The engineer's contribution to contemporary architecture: Eladio Dieste. London: Thomas Telford Publishing.

Petermans, A.M.S., Van Cleempoel, K. (2010). Designing a retail store environment for the mature market: A European perspective. Journal of Interior Design, 35(2), 21-36. https://doi.org/10.1111/j.1939-1668.2009.01036.x

Płaziak, M., Szymańska, A.I. (2014). Role of modern factors in the process of choosing a location of an enterprise. Procedia - Social and Behavioral Sciences, Elsevier, 120, 72-83.

https://doi.org/10.1016/j.sbspro.2014.02.083

Rochmińska, A. (2016). Shopping centres as the subject of Polish geographical research. Geographia Polonica, 89, 4, 521-535. https://doi.org/10.7163/GPol.0072

Rousseau, G.G., Venter, D.J.L. (2014). Mall shopping preferences and patronage of mature shoppers. SA Journal of Industrial Psychology/SA Tydskrif vir Bedryfsielkunde, 40(1), 176.

https://doi.org/10.4102/sajip.v40i1.1175

Setkowicz, P. (2008). Second Kraków kontra Bonarka City Center. Czasopismo Techniczne, 4(9), 135-141. 
Sherman, E., Mathur, A., Smith, R. (1997). Store environment and consumer purchase behaviour: Mediating role of consumer emotions. Psychology and Marketing, 14(4), 361-178. https://doi.org/10.1002/(SICI)1520-6793(199707)14:4<361::AID-MAR4>3.0.CO;2-7

Sit, J., Merrilees, B., Birch, D. (2003). Entertainment-seeking shopping centre patrons: The missing segments. International Journal of Retail and Distribution Management, 31(2), 88-94. https://doi.org/10.1108/09590550310461985

Solal, J.L. (1998). Shopping centers: The megatrends. New York: International Council of Shopping Centers.

Söllner, T. (2009). The history of shopping center development. München: GriN Verlag.

Staeheli, L.A., Mitchell, D. (2006). USA's destiny? Regulating space and creating community in american shopping malls. Urban Studies, 43(5-6), 977-992. https://doi.org/10.1080/00420980600676493

Sternquist, B. (1997). International expansion of US retailers. International Journal of Retail and Distribution Management, 25(8), 60-72. https://doi.org/10.1108/09590559710178347

Szymańska, A.I., Płaziak, M. (2017). Consumer preferences and behaviour in shopping malls in Poland with the particular reference to Krakow. Urban Development Issues, 55, 33-43. https://doi.org/10.2478/udi-2018-0003

Szymańska, A.I., Płaziak, M. (2018). Rozwój centrów handlowych w Polsce ze szczególnym uwzględnieniem galerii społecznościowych. Przedsiębiorczość - Edukacja, 14, 188-204. https://doi.org/10.24917/20833296.14.14

Szymańska, A.I., Płaziak, M. (2021). Centra handlowe i place targowe. Dwa oblicza współczesnego handlu. Wydawnictwo Uniwersytetu Pedagogicznego w Krakowie.

Szymańska, A.I. (2018). Atrakcyjność centrów handlowych jako miejsc dokonywania zakupów i korzystania z oferty usługowej w opinii respondentów. Prace Komisji Geografii Przemysłu Polskiego Towarzystwa Geograficznego, 32(2), 245-254. https://doi.org/10.24917/20801653.322.17

Teller, C. (2008). Shopping streets versus shopping malls - determinants of agglomeration format attractiveness from the consumers' point of view. The International Review of Retail, Distribution and Consumer Research 18(4), 381-403. https://doi.org/10.1080/09593960802299452

Tölle, A. (2007). Proces rewitalizacji miasta na przykładzie Poznania. Studia Regionalne i Lokalne, 2(28), 46-58.

Tubridy, M. (2006). Defining trends in shopping center history. A member perspective. Research Review, 13(1), 10-14.

Walker, S., Mesnard, X. (2012). What do mature consumers want? Research report: Global business policy council. http://www. atkearney.com/index.php/Publications

Yue-min, N. (1984). An approach to shopping centre location of Shanghai's urban area. Acta Geographica Sinica, 51(2), 163-172. 